\title{
The Determinants Of Household Savings In South Africa: A Panel Data Approach
}

Talent Zwane, University of Johannesburg, South Africa

Lorraine Greyling, Ph.D., University of Johannesburg, South Africa

Mokadi Maleka, Ph.D., University of Johannesburg, South Africa

\begin{abstract}
This study employs panel data estimation models to investigate the determinants of household savings in South Africa over the period 2008 - 2012. The novelty of some panel data models is their power to overcome the problems of endogeneity bias, in addition to controlling for unobserved heterogeneity across households. The study used the three waves of the new unique and rich first national representative longitudinal survey, the National Income Dynamics Study (NIDS), which tracks changes in individuals' livelihoods over time. The distinctiveness of NIDS data is that it is available in a panel format and can be used to investigate the structure and impact of different aspects of socioeconomic factors on household savings. The results of this study reveal that household savings in South Africa are strongly driven by income, age structure, education achievement and employment status. Yet the causal nexus between savings and the household size was found to be negative, a sign that larger families compromise households savings prospects.
\end{abstract}

Keywords: Panel Data; Household Savings; Endogeneity Bias; South Africa

\section{INTRODUCTION}

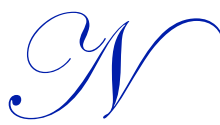

ational savings are often seen as instrumental in achieving high economic growth at a country level (Kudaisi, 2013; Amusa, 2013; Obayelu, 2012). The reasoning is simple enough: higher savings in a country generate improved investments, and investments in turn give rise to industrial growth, employment opportunities, stable prices and economic development (Rehman et al., 2011; Ogbokor and Samahiya, 2014; Suppakitjarak and Krishnamra, 2015). In the context of South Africa, understanding savings and its determinants is often complicated by the legacy of colonial disenfranchisement through legislative instruments, which left the majority of people outside the mainstream economy, excluding them from conventional savings and saving instruments (Carter and May, 2001; May and Norton, 1997). Apartheid policies negatively affected many people, especially blacks, by stripping them of their productive assets, particularly land and livestock (Carter and May, 2001), and distorting economic markets, which were the cornerstone of the poor's livelihoods and their ability to save (Hunter et al., 2003; May and Norton, 1997). The three most crucial socio-economic legacies of apartheid in South Africa are poverty, income inequality, and unemployment, which together complicate the understanding of savings and its specific determinants.

Notwithstanding these complications, it is a common practice in economics to categorise savings at a national level into two sub-categories: public savings and private savings (Kudaisi, 2013; Gedela, 2012; Rehman et al., 2011). According to Mankiw (2001), public savings are mainly associated with government, while private savings are linked to the private sector of the economy. Implicitly, the private sector of the economy can either be individual households or the corporate sector (Issahaku, 2011; Du Plessis, 2008). Of course, the government and the corporate sector are major role players in national savings, at least in terms of amount, but households remain not only the largest contributors of savings at a national level, but are also the significant beneficiaries of these savings (Mark and William, 1999; Issahaku, 2011). Some of the benefits embedded on savings include hedging against unforeseen circumstances, building of assets, investment opportunities, provision for retirement, purchasing or improving dwellings, debt settlements and acquisition of social services (Rehman et al., 2011; Choedup, 2013; Suppakitjarak and Krishnamra, 2015). 
Despite these benefits, low household savings have been a leading characteristic of the South African economy since the 1990s (South African Reserve Bank, 2012; Chipote and Tsegaye, 2014; Simlet, Keeton and Botha, 2011). As noted by the South African Reserve Bank (2012), Chipote and Tsegaye (2014) and Simlet et al. (2011), net household savings as a percentage of gross domestic product in South Africa averaged 1.63\% in the 1990 s, before dwindling further to a mere $0.35 \%$ between 2000 and 2005. Between 2006 and 2008, these figures decreased to a negligible $0.63 \%$ and a slight improvement in net values to an average of $-0.20 \%$ between 2009 and 2011. As observed by Simlet et al. (2011), low savings act as a barrier to economic growth and development, and also put pressure on the country's current account. Given that low savings are a stubborn feature of the household sector, the main aim of this study is to explicitly investigate the determinants of household savings in South Africa in an attempt to establish the reasons behind the downward trends.

While there is extensive empirical literature that has assessed the determinants of household savings in South Africa (see, Mogale et al., 2013; Simlet et al., 2011; Chipote and Tsegaye, 2014), most of these studies have implicitly or explicitly focused at macro-economic variables as explanatory factors of household savings, yet little is known about the micro aspect of savings. This lack of interest by scholars can perhaps be attributed to a lack of data needed to tackle such an analysis.

In this study, we contribute to the literature on household saving in South Africa in two ways. First we use panel data, which permits researchers to use earlier observations as instruments for the regressor variables that are not strictly exogenous (Baltagi, 2001; Schmidt-Hebbel and Serven, 1997). Thus, the study exploits three waves of the new unique and rich first national representative longitudinal survey, the National Income Dynamics Study (NIDS) that tracks changes in individual's livelihoods (SALDRU, 2009; Yu, 2012). The distinctiveness of NIDS data is that it is available in a panel format and can be used to investigate the structure and impact of the different aspects of socio-economic factors on household saving at a micro level.

Second, we complement previous studies by using recent and advanced econometric techniques. These are the panel data estimation procedure and we estimate three panel data models: the fixed effects, random effects and the two stage least square (2SLS) models. The novelty of some of these models is their ability to overcome the problems of endogeneity bias, in addition to controlling for unobserved heterogeneity in a cross-sectional unit, while presenting more accurate estimates of the coefficients related to the various factors in question (Woolridge, 2002; Greene, 2005; Islam, 1995; Hsia, 2003; Liverpool and Winter-Nelson, 2010). To the best of our knowledge, no studies have thus far used panel models to interrogate household savings, since South Africa did not have any national representative micro data, with a panel structure, until recently (NIDS was commissioned in 2008). So this study is the first in South Africa to use powerful techniques for South Africa. The remaining sections of this study are structured as follows. Section 2 presents the empirical literature, while section 3 provides the research methodology. In section 4, detailed econometric results are presented, while section 5 presents the study's concluding remarks.

\section{EMPRICAL LITERATURE}

The factors determining savings can be studied either at a macro or micro level. But most scholars have studied these factors at the macro level, with very few having shown any interest in the micro level. In addition, these studies have produced ambiguous results regarding the factors that are likely to influence household savings. Given the objective of this study, this section reviews some of these studies.

Conversely, the majority of studies that have examined the determinants of savings have made use of the lifecycle hypothesis propounded by Ando and Modigliani (1963). According to this hypothesis, an individual is a rational being who attempts to maximise utility subject to his/her budget constraints (Obayelu, 2012; Attanasio, 1999). Thus, households can spread their lifetime consumption over their lives by building savings during their earning years and drawing from these savings to smooth consumption during retirement (Adewuyi et al., 2010). Accordingly, the lifecycle hypothesis splits individuals' lifespan into two: the working phase and the period of retirement (Modigliani, 1963; Crown, 2002; Adewuyi at al., 2010). This division reveals the importance of demographic variances such as age structure in explaining individuals' saving behaviour. According to this hypothesis, households can smooth their consumption over time, taking into account the anticipated changes in their resources based on age distribution (Modigliani and Brumberg, 1954; Romer, 2012). According to the lifecycle hypothesis, households build assets during 
their working years with the aim of building a safety net when they retire (Abu et al., 2013). In other words, younger individuals tend to be net savers, while older people tend to be net borrowers (Modigliani, 1986).

Modigliani and Brumberg (1954) and Adewuyi et al. (2010) assert that individuals who are middle-aged are able to build more assets. Elbadawi and Mwega (2000), Adewuyi et al. (2010) and Abu et al. (2013) affirm that middle age is usually the appropriate age in which an individual is able to pay off some debts that were accumulated during the earlier years, and saving for retirement is imminent. The final phase is when households reach retirement age and their incomes fall to zero (Abu et al., 2013). Thus, individuals will fall back on their previous savings in order to smooth current consumption. As observed by Elbadawi and Mwega (2000), Abu et al. (2013), and Nwachukwun and Egwaikhide (2007), the lifecycle suggests that savings mainly depend on individuals' lifetime income growth. Thus, an increase in households' income significantly raises savings (Abu et al., 2013; Nwachukwun and Egwaikhide, 2007).

Although a positive correlation between household savings and income has been widely supported by various schools of thought, the causal association between these two factors remains contentious, mainly from an empirical standpoint. There are a number of studies, including those by Wakabayashi and Mackellar (1999), Horioka and Wan (2007), Mahlo (2011), and Mogale et al. (2013), that have found evidence of a positive relationship between household saving and income. In their study, Wakabayashi and Mackellar (1999) used the lifecycle hypothesis as a standard model and applied panel data for China. The data used was for the period 1993 to 1998. In a validation of the lifecycle hypothesis, the authors found that income was positively related to savings. The effect of the dependency rate on savings was found to have an inverse relationship in both the rural and urban areas of China. Arriving at similar conclusions, Horioka and Wan (2007) used Chinese provinces as a laboratory test ground and applied panel data estimation procedure utilising the 1995-2004 China's household survey. The authors found that lagged savings rate and income growth rate presented a positive and significant coefficients reinforcing the economic expectation. Yet the performance of age structure did not have a significant effect on household saving.

In South Africa the critical influence of income on saving has also been highlighted by numerous studies. For instance, Mogale et al. (2013) used Cointegrating Vector Autoregressive framework (CVAR) and observed that household savings in South Africa were unambiguously driven by income growth rate. These findings are in agreement with those of Mahlo (2011), who used ordinary least square method to examine household savings and income, consumption, interest rate and debt in South Africa. Using data from 1990 to 2009, he found a positive correlation between household savings and income, yet the nexus between savings, consumption and debt was negative. Mahlo (2011) concluded that household income is the key factor in household saving behaviour in South Africa.

In contrast, there are some studies that have disputed the conclusions of previous scholars about a positive correlation between household savings and income. In their paper, Chipote and Tsegaye (2014) used time series annual data covering 1990-2011 and applied the Johansen Cointegration and the Error Correction Mechanism for South Africa. These authors found that household income was negatively related to saving in South Africa. These results are consistent with those of Simlet et al. (2011), who concluded that an increase in South Africa's GDP leads to a simultaneous increase in consumption due to optimism, resulting in a drop in the savings rate. But these results suggest that further investigation is required to establish the factors that have a significant impact on household saving in South Africa.

\section{METHODOLOGY}

In this section, we look at the methodology applied in this study to investigate the determinants of household saving in South Africa. We build from the previous section which presented a detailed analysis of the literature review. Our first task is to present the data set and review the estimation methods, taking into account all the steps that were taken in order to draw conclusion regarding the potential factors influencing household savings in South Africa.

\subsection{Description of Data and Variables Used}

The data for this paper is generated mainly from three waves of a rich unique and first national representative longitudinal survey (NIDS), which tracks individuals over time to explore the determinants of household savings in South Africa (SALDRU, 2009; Yu, 2012). The NIDS was commissioned by the South African government, through 
The Presidency's Policy Coordination and Advisory Service in consultation with different state departments, including Statistics South Africa. The survey mainly focuses on individuals' livelihood endeavours. The NIDS is administered by the University of Cape Town, while the South African Labour and Development Research Unit (SALDRU) is the implementing agency. The NIDS is a panel study of private individuals of all ages across South Africa and is designed as a biannual survey. The first survey was conducted in 2008 with a sample size of more than 28000 individuals in 7 300 households across South Africa (SALDRU, 2009).

Consequently, individuals who were interviewed in 2008 together are re-interviewed on a biannual basis - see www.nids.uct.ac.za for a detailed description of the NIDS). The longitudinal survey continues to be repeated with the same individuals every two years, collecting both demographic and socio-economic information. According to SALDRU (2009), the project adopted a stratified two-stage sample design. The principal aim of NIDS is to get a deeper understanding of individuals who are getting ahead and those who are falling behind in South Africa (SALDRU, 2009; Yu, 2012). Moreover, it also investigates possible reasons why some individuals are making progress while others are not $(\mathrm{Yu}, 2012)$.

Following Horioka and Wan (2007), the paper uses household savings as dependent variables, while other explanatory factors are drawn from the literature. As observed in the following table, various explanatory variables used in this paper are discussed.

Table 1. Description of socio-economic factors used for empirical analysis

\begin{tabular}{l|l}
\hline \multicolumn{1}{c}{ Dependent variable } & \multicolumn{1}{c}{ Description } \\
\hline HH-savings' levels & household savings is taken as the difference between household income and expenditure \\
\hline \multicolumn{1}{c}{ Explanatory variables } & \multicolumn{1}{c}{ Description } \\
\hline HH-Income & household income is taken as the overall income received \\
\hline HH-Size & household size is the total number of members in the household \\
\hline HH-Age & age of household head (in years). \\
\hline HH-Employed & employment status of the household head $(\mathrm{empl}=1$ and unempl=0) \\
\hline HH-Gender & Gender of the head of the household (male $=1$ and female $=0)$ \\
\hline HH-Eastern Cape & household residing in Eastern cape $(1 / 0)$ \\
\hline HH-Northern Cape & household residing in Northern Cape $(1 / 0)$ \\
\hline HH-Free State & household residing in Free State $(1 / 0)$ \\
\hline HH-NwaZulu-Natal & household residing in KwaZulu-Natal $(1 / 0)$ \\
\hline HH-Gauteng & household residing in North West $(1 / 0)$ \\
\hline HH-Mpumalanga & household residing in Gauteng $(1 / 0)$ \\
\hline HH-Limpopo & household residing in Mpumalanga $(1 / 0)$ \\
\hline HH-Primary & household residing in Limpopo $(1 / 0)$ \\
\hline HH-Secondary & head of household with Matric $(1 / 0)$ \\
\hline HH-Tertiary & head of household with secondary education $(1 / 0)$ \\
\hline & head of household with tertiary education(1/0) \\
\hline
\end{tabular}

\subsection{Empirical Strategies}

As previous mentioned, the driving objective of this paper is to empirical investigate the determinants of household saving in South Africa using panel data which allows us to account for unobserved differences across households. Implicitly, heterogeneity bias in cross- sectional unit was controlled by applying our baseline model, the fixed effect model. The novelty of the fixed effect model is that it permits arbitrary correlation between the unobserved heterogeneity and explanatory variables (Greene, 2000; Kudaisi, 2013). The major drawback of the fixed effect model, its ability to control heterogeneity in cross- sectional units notwithstanding, is that the model cannot compute coefficients for time- invariant variables (Biyase, 2014). Given this issue, we then estimated the random effect model that embraces time-invariant variables (Kudaisi, 2013; Greene, 2000). Kudaisi (2013) affirms that the random effect model considers the individual effect as latent of the random factor and formally integrates them into the residual term of a linear model (Albert, 2008). Likewise, the random effect model has some setbacks in the sense that it assumes that specific effects are unrelated to other explanatory variables (Kudaisi, 2013; Albert, 2008; Abu et al., 2013). We then use the Hausman test propounded by Hausaman in 1978 to choose between the fixed effects model and the random effects model. The Hausman test checks a more efficient model over a less efficient but consistent model to 
make sure that the more efficient model also gives consistent results (Hausman, 1978; Runsinarith, 2011). According to Akbar et al. (2011), the Hausman tests the null hypothesis that the coefficients estimated by the consistent fixed effect estimator are the same $(\beta \mathrm{WG}=\beta \mathrm{RE})$ as the ones estimated by the efficient random effect estimator. If these coefficients are insignificant (more than 0.05), then it is better to use the random effects. If we get a significant pvalue (less than 0.05), however, we should use the fixed effects (Albert, 2008; Akbar et al., 2011).

Yet both the fixed effects and the random effects models have some limitations. As claimed by Horioka and Wan (2007) and Abu et al. (2013), these models assumes that the saving-income growth nexus is unidirectional and that there is no relationship between individual specific time-invariant effects and the regressors. But in their studies, Balde (2011), Loayza et al. (2000), Abu et al. (2013), Sinha and Sinha (1998), Horioka and Wan (2007) found that income growth rate was endogenous related to savings. Although a rise in an individual's income might increase savings, higher savings may also result in increased income growth (ibid). According to Abu et al. (2013), estimating such a causality would result in a potential endogeneity bias, rendering the estimates of both the fixed effect and the random effect biased and inconsistent. In the literature, it is a common practice to use 2SLS to account for endogeneity bias (Balde, 2011). This approach entails getting a factor that is highly correlated to an endogenous variable, but independent of the disturbance term (Abu et al., 2013). Balde (2011) and Bostic et al. (2009) assert that getting such variables is often difficult, but using a lagged value of explanatory factor as an internal instrument can be very helpful. Given this problem, this study used the 2SLS model to control the endogeneity bias.

\subsection{Econometric Models}

In accord with this study's objective and given the heterogeneous nature of the South African economy, this paper applies three panel data estimation techniques: the fixed effects, random effects and 2SLS models. As mentioned in the introduction, the novelty of some of these models is their ability to overcome the problems of endogeneity bias, in addition to accounting for unobserved heterogeneity in cross-sectional units (Woolridge, 2002; Greene, 2003; Kudaisi, 2013). Acknowledging the strength of panel data, we applied a balanced data set with equal observations for each household unit, and estimate the following multivariate specifications:

Fixed effects regression

$$
\operatorname{LogHSAVit}=\beta 0+\beta 1 \operatorname{LogINCO} \text { it }+\beta 2 X \mathrm{it}+\delta \text { it }+y \text { it }
$$

Random effects regression

$$
\text { LogHSAVit }=\Phi 0+\Phi 1 \operatorname{LogINCO} \text { it }+\Phi 2 X \text { it }+y \text { it }
$$

Two stage least square regression

$$
\text { LogHSAVit }=\alpha 0+\alpha 1 \operatorname{LogINCO} \text { it- } 1+\alpha 2 X \text { it }+y \text { it }
$$

Given that the lifecycle hypothesis suggests that savings depends on the growth rate of income and age structure (Adewuyi et al., 2010; Horioka and Wan, 2007), the following factors apply: $\log _{H} S A V_{i t}$ is the $\log$ of households' savings taken as the difference between income and expenditure. Yet $\operatorname{LogINCO}_{i t}$ is the $\log$ of household income, while $X_{i t}$ defines a set of control factors that reflect the peculiar characteristics of South Africa. The log treatment was based on the fact that the data used did not have negative values. Following the literature on household saving behaviour, we include the following variables in our regressions: employment status, family size, age and age square, education, gender, provincial characteristics and so forth. Given that some of our variables are in log form, their coefficients should be interpreted as elasticities. The subscript $\beta$ shows the estimated coefficients and $y_{i t}$ indicates the error term. Included in equation (2), $\delta_{i t}$ captures each individual's specific time-invariant unobservable to account for the heterogeneity bias. Based on the literature, equation 3 used the lagged value of income $\left(\operatorname{LogINCO}_{i t-1}\right)$ as a valid instrument and estimate a 2SLS to account for endogeneity bias (see Balde 2011; Abu et al., 2013). 


\section{THE EMPIRICAL RESULTS}

We began our empirical analysis by viewing the results of the Hausman specification test for the reasons stated in section 3.1 above. The test results reveal a significant Prob $>$ chi2 of 0.016 , rejecting the results of the random effect model. Based on these outcomes, the coefficient estimates of the fixed effects are more plausible in this study. The multivariate regression results of the household savings models are depicted in Table 2. Column 2 contains the outcomes of baseline model using equation (2), thus, the fixed effect model. The empirical results contained in column 6 , using equation (4), controls for a possible endogeneity using the 2SLS approach.

Since the coefficient of the Hausman test is significant, the following interpretation is primarily based on the results of the fixed effect estimations. As reported in Table 2, the regression estimates of our baseline model show that the $\log$ of income, our variable of interest, has an unambiguously positive and statistical significant effect on savings in South Africa. The findings show that when the income of a household rises, the savings levels also increases in the same direction. Thus, a $1 \%$ increase in household income will lead to $1.33 \%$ increase in savings ceteris paribus. Our results are consistent with the findings obtained by Horioka and Wan (2007), Akpan et al. (2011), Ayanwale and Bamire (2000), Rehnman et al. (2011) and Kibet et al. (2009). These results satisfy the economic expectation of positive correlation between household savings and income as postulated by Ando and Modigliani's (1963) lifecycle hypothesis. Moreover, the results of other explanatory variables have the expected signs. For instance, the employment status of the head of households exerts a positive impact on savings. These results make economic sense, since households can save only if they have employment that generates income (Issahaku, 2011).

A closer look at the savings-age nexus indicates an inverse relationship. Our findings are in agreement with the results obtained by Teshome et al. (2013). The results of age validate the lifecycle hypothesis. They suggest that as the age structure increases by one year, household saving also increases in the same direction (Rehman et al., 2010). In an attempt to capture the effect of the lifecycle hypothesis, we have used the age squared. As explained earlier, the lifecycle hypothesis claims that an increase in the age of individuals would result in an increase in their savings prospects in middle age (Rehman et al., 2011). But as an individual becomes older, his/her savings prospects diminish. Thus the results of age squared is negative and statistically significant, indicating that old-age individuals are net dissavers (Ahmad and Asghar, 2004).

Looking next at the coefficient of household size, which is another important determinant of household savings, the results indicate that household size exerts a negative and significant effect on savings in South Africa. The estimates suggest that larger household size places an extra burden on consumption expenditure; thus, more budget is diverted to consumption expenditure, resulting in lower savings. These findings also confirm the research hypothesis and the results of Akpan et al., (2011) and Nigus (2015). However, a decrease in the dependency ratio relative to the working population would ease household budget constraints, thus improving household saving prospects (Nigus, 2015).

Another important factor influencing household saving is individuals' education status. Results from the panel data reveal that education has a positive impact on household saving in South Africa. This positive impact is revealed in all categories of education, thus primary, secondary and tertiary. Apart from the positive results, the coefficients are also significant. 
Table 2. Panel data estimates of household savings in South Africa based on fixed effects and two stage least square

\begin{tabular}{l|c|c|c|c|cc}
\hline \multirow{2}{*}{} & \multicolumn{3}{|c|}{ Control for heterogeneity } & \multicolumn{2}{c}{ Correct for endogeneity } \\
\cline { 2 - 7 } & \multicolumn{2}{|c|}{ Fixed Effect Model } & \multicolumn{2}{c|}{ Random Effect Model } & \multicolumn{2}{c}{ Two Stage-Least Square } \\
\cline { 2 - 7 } & coefficient & p-value & coefficient & p- value & Coefficient & p-value \\
\hline HH-income & 1.337629 & 0.00 & 0.340244 & 0.00 & 1.38163 & 0.00 \\
\hline HH-size & -0.055637 & 0.00 & -0.004072 & 0.00 & -0.032117 & 0.00 \\
\hline HH-age & 0.0064701 & 0.08 & 0.006218 & 0.10 & 0.004655 & 0.26 \\
\hline HH-age-SQ & -0.000072 & 0.03 & -0.00071 & 0.04 & -0.00778 & 0.04 \\
\hline HH-employed & 0.0112943 & 0.66 & 0.008664 & 0.73 & 0.075356 & 0.02 \\
\hline HH-gender & 0.0369663 & 0.09 & 0.037242 & 0.09 & -0.028208 & 0.91 \\
\hline HH-Eastern Cape & -0.1038513 & 0.04 & 0.02057 & 0.72 & -0.08632 & 0.18 \\
\hline HH-Northern Cape & 0.0236158 & 0.62 & 0.082282 & 0.08 & 0.01258 & 0.01 \\
\hline HH-Free State & -0.0793328 & 0.18 & -0.045178 & 0.44 & 0.05817 & 0.36 \\
\hline HH-KwaZulu-Nat & -0.0453662 & 0.34 & -0.10159 & 0.09 & -0.09856 & 0.13 \\
\hline HH-North West & 0.1034975 & 0.07 & 0.024602 & 0.55 & 0.01059 & 0.81 \\
\hline HH-Gauteng & 0.029112 & 0.55 & 0.128342 & 0.01 & 0.13128 & 0.02 \\
\hline HH-Mpumalanga & 0.031217 & 0.57 & 0.009002 & 0.86 & 0.00420 & 0.92 \\
\hline HH-Limpopo & -0.021491 & 0.71 & 0.051422 & 0.33 & 0.08166 & 0.16 \\
\hline HH-Primary & 0.027676 & 0.37 & 0.030061 & 0.34 & 0.0219 & 0.94 \\
\hline HH-Secondary & 0.149199 & 0.00 & 0.149872 & 0.00 & 0.0910 & 0.02 \\
\hline HH-Matric & 0.277007 & 0.00 & 0.279441 & 0.00 & 0.0944 & 0.13 \\
\hline HH-Tertiary & 0.369275 & 0.00 & 0.371200 & 0.00 & 0.0988 & 0.05 \\
\hline Source: Authors' own calculations
\end{tabular}

Having presented the findings based on the fixed effect model, we now turn to the results of the 2SLS. It must be remembered that the implausible assumption underpinning the fixed effect model is that the income variable in the equation is not endogenously correlated with household savings. But if these variables are endogenously related, the estimates of the fixed effect model will be biased and inconsistent (Balde, 2011; Biyase, 2014). In the literature, it is common practice to use an instrumental variables approach, which we also adopt for this study (Abu et al., 2013). But before applying the approach, we conducted an endogeneity test under the null hypothesis that the correlation between the error term of savings and income is zero. Hence, failure to reject the null hypothesis would actually mean we cannot reject that income is exogenous to household savings. If this is the case, then the results of the fixed effect model would be more effective than those of the 2SLS model. In our study, the results of the endogeneity test show a chi-square statistic with a small p-value of 0.014 , a sign of the presence of endogeneity bias.

In an attempt to control for the endogenity bias, a powerful 2SLS approach was applied in this study. We used the lagged value of income as an internal instrument, which is a standard procedure in the literature (Abu et al., 2013). Based on the positive results of income using this technique, we conclude that the conventional wisdom that there is a positive correlation between household savings and income holds in South Africa when panel data is used. Moreover, the coefficients of other explanatory variables, such as house size, education, gender, age and age squared, are still consistent with the results of the fixed effect model. We have also included provincial categories in our analysis due to migration within South Africa. The results suggest that people in Gauteng, which is the economic hub of South Africa, are more likely to save than people in provinces such as Limpopo and Eastern Cape.

\section{CONCLUSION}

We investigated the determinants of household savings in South Africa using panel data estimation procedure for the period 2008-2012. We applied fixed effect, random effect and 2SLS models to ascertain the impact of different socioeconomic factors on savings. Panel data was preferred in this study due to its ability to overcome the problems of endogeneity bias, in addition to accounting for unobserved heterogeneity in cross-sectional units. The study used the first three waves of the national representative longitudinal survey, the NIDS, which tracks individuals over time. The novelty of the NIDS data is that it is available in a panel format and can be used to investigate the structure and impact of different aspects of socio-economic factors on household saving. Based on the positive coefficient of income found in all the estimated models, we conclude that the conventional wisdom of a positive correlation between household savings and income in South Africa hold when panel data and panel data estimation procedures are used. On the other 
hand, factors such as household size and age of the head of household were found to be negatively related to savings. It has been observed in the study that increased household size places an extra burden on households' savings. Therefore, we conclude that our finding that savings in South Africa are driven by household income is plausible.

\section{AUTHOR BIOGRAPHIES}

Talent Thebe Zwane is a Ph.D. student in the Department of Economics and Econometrics at the University of Johannesburg (South Africa), and he is also a lecturer at the University of Johannesburg (South Africa). Email: ttzwane@uj.ac.za

Lorraine Greyling is a Professor of Economics in the Department of Economics and Econometrics at the University of Johannesburg (South Africa). Her principal research is on poverty and socio-economic studies. Email: lgreyling@uj.ac.za

Mokadi Maleka, lecturer, University of Johannesburg, Department of Economics and Econometrics (South Africa). Her research interest is on poverty and inequality. Email: mrmaleka@uj.ac.za

\section{REFERENCES}

Abu, N. Zaini, M. Karim, A. \& Aziz, M. (2013). Low savings rate in the Economic Community of West African States (ECOWAS): the role of political instability-income integration. South East European Journal of Economics and Business, 8(2), pp. 53-63

Adewuyi, A. Bankole, A. B. \& Arawomo, D. F. (2010). What determines saving in the Economic Community of West African State (ECOWAS)? Journal of Monetary Economic Integration, 10(2), pp. 71-96.

African National Congress (ANC) (1994). The Reconstruction and Development Programme (Johannesburg: African National Congress)

Ahmand, M. \& Asghar, T. (2004). Estimation of saving behaviour in Pakistan using micro data. The Lahore Journal of Economics, 9(2), pp. 73-98

Akbar, A. Imdadullah, M., Ullah, M. A. \& Aslam, M. (2011). Determinants of economic growth in Asian Countries. A panel data perspective. Pakistan Journal of Social Sciences, 31 (1), pp. 145-157.

Akpan, B. Udoh, E. \& Aya Aya, E. (2011). Analysis of savings determinants among Agro- based firm workers in Nigeria: a simultaneous equation approach. Research on Humanities and Social Sciences, 1(3), pp. 1-11

Amusa, K. (2013). Savings and economic growth in South Africa: a multivariate analysis. Journal of Economic and Financial Sciences, 7(1), pp. 73-88.

Ando, A. \& Modigliani, F. (1963). The life cycle hypothesis of saving: Aggregate implications and tests. American Economic Review, 53, pp. 55-84

Balde, Y. (2011). The impact of remittances and foreign aid on savings/ investment in Sub--- Saharan Africa. African Development Review, 23, pp. 247-262.

Biyase, M. (2014). Poverty and remittances in South Africa: an instrumental variables Analysis. Environmental Economics, 5(4), pp. $40-47$

Bostic, R. Gabriel, S. \& Painter, G. (2009). Household wealth, financial wealth, and consumption: new evidence from micro data. Regional Science and Urban Economics, 39, 79-89

Carter, M. \& May, J. (2001). One kind of freedom: poverty dynamics in post-apartheid South Africa. World Development, 29(12), pp. 1987-2006

Chipote, P. \& Tsegaye, A. (2014). Determinants of household savings in South Africa: an econometric approach (1990-2011). Mediterranean Journal of Social Sciences, 5(15), pp. 183-190.

Choedup, T. (2013). Analysing household saving determinants in Bhutan. International Journal of Humanities and Management Sciences, 1(2), pp. 179-183

Du Plessis, G. (2008). An exploration of the determinants of South Africa's personal savings rate - Why do South African households save so little?, MBA dissertation, University of Pretoria, Pretoria, viewed $131204<$ http://upetd.up.ac.za/thesis/available/etd-03122010-141825/ >

Elbadawi, I. A \& Mwega, F. M. (2000). Can Africa's saving collapse be reversed? The World Bank Economic Review, 14(3), pp. $415-444$.

Gedela, S. P. R. (2012). Determinants of saving behaviour in rural and tribal households: Empirical analysis of Visakhapatnam District. International Journal of Research in Social Sciences, 2(3), pp. 108-128.

Greene, W.H. (2003). Econometric analysis. 5th Edn.: Pearson Education, Inc.

Hsiao, C. (2003). Analysis of panel data. 2nd edition. United Kingdom: Cambridge University Press, 1-7 
Horioka, C. Y. \& Wan, J. (2007). The determinants of household saving in China: a dynamic panel analysis of provincial data. Journal of Money, Credit and Banking, 39(8), pp. 2077- 2096.

Hunter, N. May, J \& Padayachee, V. (2003). Lessons for PRSP from poverty reduction strategies in South Africa. Working Paper No 39.

Issahaku, H. (2011). Determinants of saving and investment in deprived district capitals in Ghana: a case study of Nadoli in the west region of Ghana. Continental Journal of Social Sciences, 4, pp. 1-11

Kibet, L. Mutai, B. Ouma, E., Ouma S. \& Owuor, G. (2009). Determinants of Household Saving: Case Study of smallholder farmers, entrepreneurs and teachers in rural areas of Kenya. Journal of Development and Agricultural Economics, 1(7), pp. 137-143.

Kudaisi, B. V. (2013). Savings and its determinants in West Africa countries. Journal of Economics and Sustainable Development, 18(18), pp. 107-119.

Kulikov, D. Paabut, A. \& Staehr, K. (2007). A micro econometric analysis of household saving in Estonia: income, wealth and financial exposure. Working Paper 8/2007.

Liverpool, L. \& Winter-Nelson, A. (2010). Asset versus Consumption Poverty and Poverty Dynamics in the Presence of Multiple Equilibria in Rural Ethiopia. International food Policy Research Institute, IFPRI Discussion Paper 00971

Loayza, N. Schmidt-Hebbel, K. \& Serven, L. (2000). What drives private saving across the world? Review of Economics and Statistics, 82 (2), pp. 162-181.

Mankiw, N.G. (2001). Principles of economics. 2nd Edn: Harcart College publishers.

Mahlo, N. (2011). The determinants of household savings in South Africa. University of Johannesburg.

Malumisa, S. (2013). Comparative analysis of the determinants and behaviour of investment demand between South Africa and Zimbabwe. Journal of Economics and Behavioural Studies, 5(6), pp.

May, J. \& Norton, A. (1997). A difficult life: The perceptions and experience of poverty in South Africa. Social Indicators Research, 41, pp. 95-118.

Modigliani, F. \& Ando, A. (1983). The Life Cycle Hypothesis of Saving; Aggregate Implications and Taste. American Economic Review, 53(1), pp. $55-84$.

Modigliani, F. \& Bumberg, A. (1954). Test of the life cycle hypothesis of saving. Bullerin of the Oxford Institute of Statistics, 19, pp. 99-124

Mogale, I.P. Mukuddem-Petersen, J. Petersen, M. A. \& Meniago, C. (2013). Household saving in South Africa: An Econometric Analysis. Mediterranean Journal of Social Sciences, 4(13), pp. 519-530

Nigus, H. (2015). Determinants of Household Saving in Gedeo Zone, Southern Ethiopia. Journal of Economics and Sustainable Development. 6(7), pp. 93 - 102

Nwachukwu, T. \& Egwaikhide, F. (2007). An error-correctional model of the determinants of private savings in Nigeria. University of lbadan, Nigeria.

Obayelu, A. (2012). Savings behaviour of rural household in Kwara State, Nigeria. African Journal of Basic and Applied Sciences, 4 (4), pp. 115-123

Ogbokor, C. A. (2014). A time series analysis of the determinants of savings in Namibia. Journal of Economic and Sustainable Development, 5 (8), pp. 52-63.

Ozcan, M. Gunay, A. \& Ertac, S. (2012). Macro and socioeconomic determinants of Turkish private savings. Journal of Economic and Cooperation and Development, 33(2), pp. 93-130

Rehman, H. Bashir, F. \& Faridi, M. Z. (2011). Saving behaviour among different income groups in Pakistan: A micro study. International Journal of Humanities and Social Science, 1 (10), pp. 268-276.

Rehman, H. Faridi, Z \& Bashir, F. (2010). Household saving behaviour in Pakistan: a case of Multan district. Pakistan Journal of Social Sciences, 30 (1), pp. 17-29.

Romer, D. (2005). Advanced Macroeconomics 3rd edition, University of California, Berkeley.

Sinha, D. \& Sinha, T. 1998. Cart before the horse? The saving growth nexus in Mexico. Economics Letters 61: 43-47.

Simlet, C. Keeton, G. \& Botha, F. (2011). The determinants of household savings in South Africa. Journal of Studies in Economics and Econometrics, 35(3), pp. 1- 19

South African Reserve Bank, (2012). Quarterly Bulletin, June 2012. No. 264

Southern Africa Labour Development Research Unit (2009). National Income DynamicsStudy Wave 1: User document. Cape Town: Southern Africa Labour and Development Research Unit, University of Cape Town.

Suppakitjarak, N. \& Krishnamra, P. (2015). Household Saving Behaviour and Determinants of the Forms of Saving and Investment in Thailand. Journal of Economics, Business and Management, 3(3), pp. 326-330

Yu, K. C. (2012). Using household surveys for deriving labour market, poverty and inequality trends in South Africa. Dissertation presented for the degree of Doctor of Economics in the Faculty of Economics and Management Sciences at the University of Stellenbosch.

Teshome, G. Kassa, B. and Haji, B. E. (2013). Determinants of Rural Household Savings in Ethiopia: The Case of East Hararghe Zone, Oromia Regional State. Journal of Economics and Sustainable Development. Vol.4 (3): 66 - 76

Wakabayashi, M. \& Mackellar, L. (1999). Demographic trends and household savings in China. Interim Report, International Institute for Applied System Analysis.

Wooldridge, J. (2002). Econometric Analysis of Cross Section and Panel Data. MIT Press, Boston, USA. 


\section{NOTES}

